\title{
Vasorelaxing effects of estetrol in rat arteries
}

\author{
Rob H P Hilgers, Suzanne Oparil, Wout Wouters ${ }^{1}$ and Herjan J T Coelingh Bennink ${ }^{1}$ \\ Division of Cardiovascular Disease, Department of Medicine, Vascular Biology and Hypertension Program, University of Alabama at Birmingham, 1034 Zeigler \\ Research Building, 703 19th Street South, Birmingham, Alabama 35294-0007, USA \\ ${ }^{1}$ Pantarhei Bioscience, Zeist, The Netherlands \\ (Correspondence should be addressed to S Oparil; Email: soparil@uab.edu)
}

\begin{abstract}
This study compared ex vivo relaxing responses to the naturally occurring human hormone estetrol $\left(\mathrm{E}_{4}\right)$ vs $17 \beta$-estradiol $\left(\mathrm{E}_{2}\right)$ in eight different vascular beds. Arteries were mounted in a myograph, contracted with either phenylephrine or serotonin, and cumulative concentrationresponse curves (CRCs) to $\mathrm{E}_{4}$ and $\mathrm{E}_{2}(0 \cdot 1-100 \mu \mathrm{mol} / \mathrm{l})$ were constructed. In all arteries tested, $\mathrm{E}_{4}$ had lower potency than $E_{2}$, although the differential effect was less in larger than smaller arteries. In uterine arteries, the nonselective estrogen receptor (ER) blocker ICI $182780(1 \mu \mathrm{mol} / \mathrm{l})$ caused a significant rightward shift in the CRC to both $\mathrm{E}_{4}$ and $\mathrm{E}_{2}$, indicating that the relaxation responses were $\mathrm{ER}$ dependent. Pharmacological blockade of nitric oxide (NO) synthases by $N^{\omega}$-nitro-L-arginine methyl ester (L-NAME) blunted $\mathrm{E}_{2}$-mediated but not $\mathrm{E}_{4}$-mediated relaxing responses, while inhibition of prostaglandins and endothelium-dependent
\end{abstract}

hyperpolarization did not alter relaxation to either $\mathrm{E}_{4}$ or $\mathrm{E}_{2}$ in uterine arteries. Combined blockade of $\mathrm{NO}$ release and action with L-NAME and the soluble guanylate cyclase $(\mathrm{sGC})$ inhibitor ODQ resulted in greater inhibition of the relaxation response to $E_{4}$ compared with $E_{2}$ in uterine arteries. Endothelium denudation inhibited responses to both $E_{4}$ and $E_{2}$, while $E_{4}$ and $E_{2}$ concentration-dependently blocked smooth muscle cell $\mathrm{Ca}^{2+}$ entry in $\mathrm{K}^{+}$-depolarized and $\mathrm{Ca}^{2+}$-depleted uterine arteries. In conclusion, $\mathrm{E}_{4}$ relaxes precontracted rat arteries in an artery-specific fashion. In uterine arteries, $\mathrm{E}_{4}$-induced relaxations are partially mediated via an endothelium-dependent mechanism involving ERs, sGC, and inhibition of smooth muscle cell $\mathrm{Ca}^{2+}$ entry, but not NO synthases or endothelium-dependent hyperpolarization.

Journal of Endocrinology (2012) 215, 97-106

\section{Introduction}

The hormone estetrol (estra-1,3,5(10)-trien-3,15 $\alpha$ $16 \alpha, 17 \beta$-tetrol or $\mathrm{E}_{4}$ ) was discovered in 1965 (Hagen et al. $1965) . \mathrm{E}_{4}$ is produced in nature from $17 \beta$-estradiol $\left(\mathrm{E}_{2}\right)$ and estrol $\left(\mathrm{E}_{3}\right)$ only by the human fetal liver during pregnancy via $15 \alpha$ - and $16 \alpha$-hydroxylase (Schwers et al. 1965, Gurpide et al. 1966). The concentration of $\mathrm{E}_{4}$ increases during pregnancy in both the fetus and the mother, but $24 \mathrm{~h}$ after delivery, the level is undetectable.

The chemical structure of $E_{4}$ is closely related to that of $E_{2}$, but the pharmacokinetic, metabolic, and endocrinological profile of $E_{4}$ is substantially different from that of $E_{2}$. $E_{2}$ has high affinity for the estrogen receptor $\alpha(E R \alpha)$ and $\operatorname{ER} \beta$ ( $K_{\mathrm{i}}$ values: 0.2 and $0.05 \mathrm{nmol} / 1$ respectively), while $\mathrm{E}_{4}$ has low-to-moderate affinity for $\operatorname{ER} \alpha$ and $\operatorname{ER} \beta$ ( $K_{\mathrm{i}}$ values: 4.9 and $19 \mathrm{nmol} / 1$ respectively; Coelingh Bennink et al. 2008a). $\mathrm{E}_{2}$ has very low oral availability because over $99 \%$ of an oral dose is converted into estrone $\left(\mathrm{E}_{1}\right)$ and $\mathrm{E}_{1}$ sulfate. Most of the circulating $E_{2}$ is bound to either albumin or sex hormone binding globulin (SHBG), further decreasing plasma levels of free $\mathrm{E}_{2}$ by a factor of about 30 . By contrast, $\mathrm{E}_{4}$ does not undergo phase I metabolism by human HepG2 cells and does not bind to SHBG (Hammond et al. 2008). As a result of these favorable metabolic and protein binding properties, $\mathrm{E}_{4}$ has excellent oral potency despite its low-to-moderate affinity for ERs.

$\mathrm{E}_{4}$ has been studied in many validated models and has been shown to behave as a full ER agonist, similar to $\mathrm{E}_{2}$, in most of these (Coelingh Bennink et al. 2008b, Heegaard et al. 2008, Holinka et al. 2008, Visser \& Coelingh Bennink 2009). However, important differences between $\mathrm{E}_{4}$ and $\mathrm{E}_{2}$ were noted. $\mathrm{E}_{4}$ did not induce synthesis of SHBG in vitro as did $\mathrm{E}_{2}$ (Hammond et al. 2008). Recent studies showed that $\mathrm{E}_{4}$ behaved as an ER antagonist in in vitro and in vivo models of estrogen-dependent breast tumors in the presence of $E_{2}$. $E_{2}$ behaved as full agonist in these models (Coelingh Bennink et al. 2008c). $\mathrm{E}_{4}$ is now undergoing clinical testing as the estrogenic component of a combined oral contraceptive and for its effects on breast tumors.

The physiological function of $\mathrm{E}_{4}$ is not completely understood, although a role in regulating uterine blood flow has been suggested. Unilateral intrauterine injection of $\mathrm{E}_{4}$ in nonpregnant oophorectomized ewes has been shown to increase uterine blood flow, although with a 15- to 30-fold lower potency than $E_{3}$ (Levine et al. 1984). Similarly, 
administration of $\mathrm{E}_{2}$ to ovariectomized ewes results in a rapid uterine vasodilation leading to a rise in uterine blood flow within 30-45 min (Killam et al. 1973). This rise in uterine blood flow is partially mediated via the release of nitric oxide (NO) and resultant increases in cGMP secretion, as shown by local infusion of the NO synthase blocker $N^{\omega}$-nitro-L-arginine methyl ester (L-NAME; Van Buren et al. 1992, Rosenfeld et al. 1996). The dilating effect of $E_{2}$ on ovine uterine arteries is ER dependent, as shown by local infusion of the nonselective ER blocker ICI 182780 in nonpregnant ewes (Magness et al. 2005).

To further profile $\mathrm{E}_{4}$, this study was designed to study the in vitro vasorelaxing effects of $\mathrm{E}_{4}$ and to compare them with those of $E_{2}$. The objectives of this study were 1) to determine the ex vivo relaxing effects of $\mathrm{E}_{4}$ compared to $\mathrm{E}_{2}$ in rat uterine, thoracic aortic, carotid, mesenteric, pulmonary, renal, middle cerebral, and septal coronary arterial segments; 2) to assess the involvement of ERs in the vasorelaxing response to $E_{4}$ in uterine arteries; and 3) to assess the endothelium-dependent and endothelium-independent vasorelaxing effects of $E_{4}$ in uterine arteries. The uterine artery was chosen for assessment of the acute vasoactive properties of $\mathrm{E}_{4}$ and for comparison of these to the effects of $E_{2}$ because the uterine arterial circulation is known to be highly sensitive to the vasodilator effects of $\mathrm{E}_{2}$. The uterine arteries are exposed to high physiological levels of $E_{2}$ during the follicular and luteal phases of the menstrual cycle and during pregnancy, resulting in major increases in uterine blood flow (Magness 1998).

\section{Materials and Methods}

\section{Animals}

A total of 40 female nulliparous Sprague Dawley rats (age 12 weeks) were obtained from Charles River Breeding Laboratories, maintained at constant humidity $(60 \pm 5 \%)$, temperature $\left(24 \pm 1{ }^{\circ} \mathrm{C}\right)$, and light cycle $(0600-1800 \mathrm{~h})$, and fed a standard rat pellet diet (2016 Teklad Global 16\% Protein Rodent Diet (Harlan Laboratories, Teklad Diets, Madison, WI, USA) ad libitum. All protocols were approved by the Institutional Animal Care and Use Committee at the University of Alabama at Birmingham and were consistent with the Guide for the Care and Use of Laboratory Animals published by the National Institutes of Health.

\section{Vessel preparation}

Rats were killed by $\mathrm{CO}_{2}$ inhalation and the uterus, thoracic aorta, left common carotid artery, mesentery, lungs, left kidney, brains, and heart were removed and placed in cold KrebsRinger buffer (KRB) with the following composition (in $\mathrm{mM}$ ): $118.5 \mathrm{NaCl}, 4.7 \mathrm{KCl}, 2.5 \mathrm{CaCl}_{2}, 1.2 \mathrm{MgSO}_{4}$, $1 \cdot 2 \mathrm{KH}_{2} \mathrm{PO}_{4}, 25 \cdot 0 \mathrm{NaHCO}_{3}$, and $5 \cdot 5$ glucose (all purchased from Sigma-Aldrich). Tissue samples were pinned down onto a $90 \mathrm{~mm}$ glass petri dish coated with black Sylgard and soaked in cold KRB. Main uterine arterial segments running along both uterine horns were cleared of adipose and connective tissues. The thoracic aorta and left common carotid artery were cleaned of connective tissue and cut into $2 \cdot 5-3 \mathrm{~mm}$ segments. A fourth-order branch segment of the superior mesenteric artery was dissected from the mesentery; a small (200-300 $\mu \mathrm{m}$ in diameter) pulmonary arterial segment was dissected from the lung; a segment of the left main renal artery was dissected, and a segment of the middle cerebral artery was dissected from the brain. The atria and the left ventricle were removed to expose the interventricular septum of the heart, and a segment of the septal coronary artery was dissected. Aortic and carotid artery segments were mounted between two stainless steel pins, whereas the other segments (all $2 \mathrm{~mm}$ long) were mounted between two stainless steel jaws connected with two wires ( $40 \mu \mathrm{m}$ in diameter) through the lumen of the segment in a myograph chamber (Danish Myo Technology, Inc., Aarhus, Denmark) filled with $5 \mathrm{ml} \mathrm{KRB}$ solution, maintained at $37^{\circ} \mathrm{C}$, and continuously aerated with $95 \% \mathrm{O}_{2}$ and $5 \% \mathrm{CO}_{2}$. Four arterial segments were analyzed in parallel. The remaining segments were temporarily stored at $4^{\circ} \mathrm{C}$.

\section{Determination of optimal diameters}

Thoracic aortae and carotid and pulmonary arteries were passively stretched according to a procedure first described by Mulvany \& Halpern (1977). Briefly, the segments were distended stepwise in $100 \mu \mathrm{m}$ increments measured with a built-in micrometer and the wall tension $(\mathrm{N} / \mathrm{m})$ was recorded using data acquisition (Powerlab 8/35, ADInstruments, Colorado Springs, CO, USA) and recording Software (ChartLab7, Colorado Springs, CO, USA). Thoracic aortic segments and carotid arteries were stretched at wall tension corresponding to a pressure of $90 \mathrm{mmHg}$, whereas pulmonary arteries were stretched at a wall tension corresponding to $40 \mathrm{mmHg}$. At this passive wall tension, segments were contracted with high $\mathrm{K}^{+} \mathrm{KRB}(60 \mathrm{mmol} / \mathrm{l}$ $\mathrm{KCl}$ in $\mathrm{KRB}$ solution; replacing equimolar $\mathrm{NaCl}$ with $\mathrm{KCl}$ ), thus generating active wall tension, which was set to a $100 \%$ contraction level.

All other arterial segments were progressively and actively stretched to the internal diameter at which the largest contractile response to $10 \mu \mathrm{mol} / 1$ norepinephrine (NE) or $60 \mathrm{mmol} / \mathrm{l} \mathrm{K}^{+} \mathrm{KRB}$ (middle cerebral arteries) was obtained. This internal diameter was referred to as the optimal diameter and the corresponding active wall tension was set to a $100 \%$ contraction level.

Arterial integrity was assessed by contracting arterial segments to either $1 \mu \mathrm{mol} / 1$ phenylephrine (PHE; for uterine, thoracic aorta, carotid, mesenteric, pulmonary, and renal arteries) or $0 \cdot 1-1 \mu \mathrm{mol} / 1$ serotonin (5-HT; for middle cerebral and septal coronary arteries), followed by endothelium-dependent relaxation with $1 \mu \mathrm{mol} / 1$ acetylcholine (ACh). Arteries that relaxed immediately ( $>50 \%$ of relaxation) were considered to have a functional endothelium. 


\section{Experimental protocols}

Cumulative concentration-response curves (CRCs) were constructed with PHE $(0 \cdot 16-20 \mu \mathrm{mol} / \mathrm{l})$ or 5 -HT $(0 \cdot 001-10 \mu \mathrm{mol} / \mathrm{l})$. Arterial segments were then washed with KRB and after $10 \mathrm{~min}$ were contracted with a single concentration of the appropriate contractile agent, resulting in a near maximal contraction $(80-100 \%$ of active wall tension obtained with $10 \mu \mathrm{mol} / 1 \mathrm{NE}$ or $60 \mathrm{mmol} / 1 \mathrm{~K}^{+}$ depolarization). During a stable contraction, a CRC to $\mathrm{E}_{4}$ $(0 \cdot 1-100 \mu \mathrm{mol} / \mathrm{l})$ was performed. After a 30-min washout period, segments were again contracted with the appropriate contractile agent and the CRC was repeated with $\mathrm{E}_{2}$ $(0 \cdot 1-100 \mu \mathrm{mol} / \mathrm{l})$. The order of application of the estrogenic compounds was altered on every experimental day. In a subset of uterine arteries, CRCs to $\mathrm{E}_{4}$ and $\mathrm{E}_{2}$ were run in parallel. Relaxing responses to $E_{2}$ and $E_{4}$ were unaltered when run in series compared with parallel application.

We constructed CRCs to the selective ER $\alpha$ agonist propyl-[1H]-pyrazole-1,3,5-triy-triphenol (PPT; 0.1-30 $\mu \mathrm{mol} / 1$; Stauffer et al. 2000) and the selective ER $\beta$ agonist 2,3-bis(4-hydroxyphenol)-propionitrile (DPN; 0.1-30 $\mu \mathrm{mol} / 1$; Meyers et al. 2001) and compared their uterine arterial relaxing responses to $\mathrm{E}_{4}$ and $\mathrm{E}_{2}$. To study the involvement of ERs $(E R \alpha$ and $E R \beta)$ in the uterine arterial relaxing responses to $E_{4}$ in comparison to $E_{2}$, arteries were incubated for $30 \mathrm{~min}$ with the nonselective $\mathrm{ER}$ antagonist ICI 182780 (7a,17b-[9-[(4,4,5,5,5-pentafluoropentyl) sulfinyl]nonyl] estra-1,3,5(10)-triene-3,17-diol; $1 \mu \mathrm{mol} / 1$; Wakeling et al. 1991), after which the arterial segments were contracted with a single concentration of PHE (1-10 $\mu \mathrm{mol} / \mathrm{l})$ followed by a CRC to either $\mathrm{E}_{4}$ or $\mathrm{E}_{2}$.

To assess whether $\mathrm{E}_{4}$ triggered the release of vasodilator and/or contractile prostaglandins in uterine arteries, the cyclooxygenase inhibitor indomethacin (INDO; $10 \mu \mathrm{mol} / \mathrm{l}$ ) was used. The involvement of endothelium-derived $\mathrm{NO}$ in uterine arterial relaxing responses to $\mathrm{E}_{4}$ was assessed using the nonselective NO synthase blocker L-NAME $(100 \mu \mathrm{mol} / \mathrm{l})$. The combined application of L-NAME and INDO was used to assess the role of endothelium-derived hyperpolarizing factor (EDHF) in $\mathrm{E}_{4}$-mediated relaxing responses in uterine arteries. The involvement of cGMP in $\mathrm{E}_{4}$-mediated relaxation was assessed by incubating uterine arteries with L-NAME, INDO, and the soluble guanylate cyclase (sGC) inhibitor $1 \mathrm{H}-$ [1,2,4] oxadiazolo[4,3-a]quinoxalin-1-one (ODQ; $10 \mu \mathrm{mol} / \mathrm{l})$.

The hyperpolarization response, involving both release of EDHF and spread of a hyperpolarizing current, is initiated in the endothelium via activation of small and intermediate calcium-activated $\mathrm{K}^{+}$channels $\left(\mathrm{SK}_{\mathrm{Ca}}\right.$ and $\mathrm{IK}_{\mathrm{Ca}}$ respectively; Burnham et al. 2002). Blockade of both $\mathrm{K}_{\mathrm{Ca}}$ channels results in complete blockade of the EDHF response in rat mesenteric arteries (Crane et al. 2003). However, in some arteries, such as skeletal arterioles and coronary arteries, the large-conductance $\mathrm{K}_{\mathrm{Ca}}\left(\mathrm{BK}_{\mathrm{Ca}}\right)$ is involved in EDHF-mediated responses (Feher et al. 2010). We did not attempt to study the role of the $\mathrm{BK}_{\mathrm{Ca}}$ channel blocker iberiotoxin in $\mathrm{E}_{4^{-}}$and $\mathrm{E}_{2}$-mediated relaxing responses in uterine arteries. 6,12,19,20,25,26Hexahydro-5,27:13,18:21,24-trietheno-1 1,7-metheno-7Hdibenzo $[\mathrm{b}, \mathrm{n}][1,5,12,16]$ tetraazacyclotricosine-5,13-diium dibromide (UCL 1684; $1 \mu \mathrm{mol} / \mathrm{l}$; Campos Rosa et al. 2000) was used to block $\mathrm{SK}_{\mathrm{Ca}}$ channels and 1-[(2chlorophenyl)diphenylmethyl]-1H-pyrazole (TRAM-34; $1 \mu \mathrm{mol} / \mathrm{l}$; Wulff et al. 2000) was used to block $\mathrm{IK}_{\mathrm{Ca}}$ channels. All inhibitors were applied $30 \mathrm{~min}$ before the addition of PHE. After washing with KRB, arterial segments were again incubated with the appropriate pharmacological blocker(s) and subsequently (after $10 \mathrm{~min}$ ) contracted with PHE (1-10 $\mu \mathrm{mol} / \mathrm{l})$ followed by a CRC to either $\mathrm{E}_{4}$ or $\mathrm{E}_{2}$.

The role of endothelium in $\mathrm{E}_{4}$-mediated relaxing responses was assessed using endothelium-denuded uterine arteries. The endothelium was mechanically removed by gently rubbing the lumen with a human hair (Osol et al. 1989). Successful denudation was achieved when relaxation to $1 \mu \mathrm{mol} / 1$ ACh was absent. Endothelium-independent relaxing responses to the $\mathrm{NO}$ donor sodium nitroprusside (SNP; 0.1-10000 nmol/l) were performed in PHE $(10 \mu \mathrm{mol} / \mathrm{l})$-contracted endothelium-intact arteries.

The potential inhibitory effect of $\mathrm{E}_{4}$ on voltage-operated smooth muscle cell $\mathrm{Ca}^{2+}$ entry was assessed by incubating endothelium-intact uterine arteries with three different concentrations $(10,30$, and $100 \mu \mathrm{mol} / \mathrm{l})$ of $\mathrm{E}_{4}$ or vehicle (ethanol) for $10 \mathrm{~min}$ in $\mathrm{Ca}^{2+}$-free and high $\mathrm{K}^{+} \mathrm{KRB}$ solution, followed by a cumulative addition of $\mathrm{CaCl}_{2}$ $(0 \cdot 01-2 \cdot 5 \mathrm{mmol} / \mathrm{l})$. To rule out modulating effects of other endothelium-derived relaxing factors, arteries were incubated with L-NAME $(100 \mu \mathrm{mol} / \mathrm{l})$, INDO $(10 \mu \mathrm{mol} / \mathrm{l})$, and ODQ $(10 \mu \mathrm{mol} / \mathrm{l})$. Results were compared with three different concentrations $(3,10$, and $30 \mu \mathrm{mol} / \mathrm{l})$ of $\mathrm{E}_{2}$.

\section{Drugs}

$\mathrm{E}_{4}$ was provided by Pantarhei Bioscience B.V. (Zeist, The Netherlands) and dissolved in ethanol (stock solution of $10 \mathrm{mmol} / \mathrm{l})$. ACh, endothelin-1, L-NAME, NE, PHE, serotonin, and SNP were purchased from Sigma-Aldrich and dissolved in distilled $\mathrm{H}_{2} \mathrm{O}$. INDO and $\mathrm{E}_{2}$ (Sigma-Aldrich) were dissolved in ethanol (stock solutions of $10 \mathrm{mmol} / \mathrm{l}$ ). TRAM-34 (Sigma), ODQ (EMD Chemicals, Gibbstown, NJ, USA), PPT, DPN, and UCL 1684 (all from Tocris Bioscience, Ellisville, MO, USA) were dissolved in DMSO.

\section{Data and statistical analysis}

Contractile responses were expressed as a percentage of the maximal contractile response to $10 \mu \mathrm{mol} / 1 \mathrm{NE}$ or $60 \mathrm{mmol} / 1 \mathrm{~K}^{+}$before the administration of any pharmacological inhibitor. Relaxing responses were expressed as a percentage of the maximal contractile response to PHE or 5HT. Individual CRCs were fitted to a sigmoid regression curve (GraphPad Prism 5.0). As the sigmoidal curve of $\mathrm{E}_{4}$ could not be fully defined, a constant plateau value (set to $100 \%$ ) was defined in order for GraphPad Prism to calculate 
Table 1 Optimal diameters and active wall tensions to $\mathrm{NE}(10 \mu \mathrm{mol} / \mathrm{l})$ or depolarizing potassium $\left(\mathrm{K}^{+}\right)$solution $(60 \mathrm{mmol} / \mathrm{l} \mathrm{KCl}$ in Krebs-Ringer solution) for rat uterine, aortae, carotid, mesenteric, pulmonary, renal, middle cerebral, and septal coronary arteries. Uterine, mesenteric, pulmonary, and renal arteries were contracted with NE. Aortae, carotid, middle cerebral, and septal coronary arteries were contracted with depolarizing $\mathrm{K}^{+}$solution. When more arteries of the same type were isolated from one rat, the values were averaged per rat. Values are shown as mean \pm S.E.M.

\begin{tabular}{|c|c|c|c|c|c|c|c|c|}
\hline Artery type & Uterine & Aorta & Carotid & Mesenteric & Pulmonary & Renal & $\begin{array}{l}\text { Middle } \\
\text { cerebral }\end{array}$ & $\begin{array}{l}\text { Septal } \\
\text { coronary }\end{array}$ \\
\hline Optimal diameter $(\mu \mathrm{m})$ & $317 \pm 3$ & $1467 \pm 17$ & $587 \pm 7$ & $228 \pm 5$ & $217 \pm 9$ & $478 \pm 19$ & $232 \pm 4$ & $247 \pm 7$ \\
\hline Active wall tension $(\mathrm{N} / \mathrm{m})$ & $4 \cdot 81 \pm 0 \cdot 10$ & $5 \cdot 24 \pm 16$ & $2 \cdot 07 \pm 0 \cdot 11$ & $2 \cdot 41 \pm 0 \cdot 09$ & $1 \cdot 51 \pm 0 \cdot 16$ & $4 \cdot 92 \pm 0 \cdot 29$ & $1 \cdot 41 \pm 0 \cdot 10$ & $0 \cdot 88 \pm 0 \cdot 07$ \\
\hline$n$ & $\overline{40}$ & $\overline{6}$ & $\overline{27}$ & $\overline{27}$ & $\overline{11}$ & $\overline{24}$ & $\overline{24}$ & $\overline{19}$ \\
\hline
\end{tabular}

NE, norepinephrine. $n$ denotes the total number of rats used.

a LOGEC $_{50}\left(\mathrm{pEC}_{50}\right.$ value indicating sensitivity). Maximal relaxation to the highest concentration of $E_{4}$ or $E_{2}\left(E_{\max }\right)$ and $\mathrm{pEC}_{50}$ values are shown as mean \pm s.E.M. Statistical significance of effects and differences were analyzed using either one-way ANOVA (comparison of $\mathrm{pEC}_{50}$ and $\mathrm{E}_{\max }$ ) or twoway ANOVA (comparison of CRCs). A Bonferroni post hoc test was used to compare multiple groups. A $P$ value $<0 \cdot 05$ was considered statistically significant.

\section{Results}

\section{Arterial integrity}

Optimal diameters of uterine arteries measured in the wire myograph averaged $317 \pm 3 \mu \mathrm{m}$ and arteries developed an average active wall tension of $4 \cdot 81 \pm 0 \cdot 10 \mathrm{~N} / \mathrm{m}$ in response to $10 \mu \mathrm{mol} / 1 \mathrm{NE}$. Optimal diameters and active wall tensions for all artery types are summarized in Table 1 . Sensitivity $\left(\mathrm{pEC}_{50}\right)$ and maximal contraction to PHE (uterine, carotid, mesenteric, pulmonary, and renal artery) or 5-HT (middle cerebral and septal coronary artery) and sensitivity and maximal relaxations to $1 \mu \mathrm{mol} / \mathrm{ACh}$ and the $\mathrm{NO}$ donor SNP for all arteries are shown in Table 2.

\section{Vasorelaxing responses to $E_{4}$}

In uterine arteries, $\mathrm{pEC}_{50}$ for the control estrogenic compound $\mathrm{E}_{2}$ averaged 5.44 $\pm 0 \cdot 05$ and reached a near maximal relaxation $\left(\mathrm{E}_{\max }: 93 \pm 1 \%\right)$ in response to the highest concentration tested $(100 \mu \mathrm{mol} / 1$; Tables 3 and 4 and Fig. 1A). $\mathrm{pEC}_{50}$ and $\mathrm{E}_{\max }$ for $\mathrm{E}_{4}$ were significantly lower $(4 \cdot 36 \pm 0.07$ and $74 \pm 4 \%$ respectively; Tables 3 and 4 and Fig. 1A). Hence, in uterine arteries, $\mathrm{E}_{4}$ was a 14 -fold less potent vasodilator compared with $\mathrm{E}_{2}$. Vasorelaxing properties of $E_{4}$ compared with $E_{2}$ for the other seven arterial types are shown in Fig. 1B through $\mathrm{H}$ and are summarized in Tables 3 and $4 . \mathrm{E}_{4}$ resulted in much lower variability than $\mathrm{E}_{2}$ in $\mathrm{pEC}_{50}$ and $E_{\max }$ values for all artery types tested (Tables 3 and 4). Larger arteries (aorta, carotid, and renal) had lower $\mathrm{pEC}_{50}$ and $\mathrm{E}_{\max }$ than smaller arteries (mesenteric, pulmonary, middle cerebral, septal coronary, and uterine).

Table 2 Contractile characteristics to phenylephrine or serotonin, responses to a single concentration of ACh ( $1 \mu \mathrm{mol} / \mathrm{l})$, and cumulative concentrations of SNP in contracted rat uterine, carotid, mesenteric, middle cerebral, pulmonary, renal, and septal coronary arteries.

Sensitivity $\left(\mathrm{pEC}_{50}\right)$ to contractile agents and to the NO donor SNP is calculated by GraphPad Prism Software as described in the Materials and Methods section and represents the negative logarithmic concentration of the contractile agent that induces a $50 \%$ tension level compared to $E_{\max }$. Maximal contraction to contractile agent $\left(E_{\max }\right)$ is calculated at the percentage tension compared to the AWT corresponding to the artery's optimal diameter. The percentage contraction before ACh application is calculated as the percentage tension compared to the AWT corresponding to the artery's optimal diameter. Values are shown as mean \pm s.E.M.

\begin{tabular}{|c|c|c|c|c|c|c|c|}
\hline Artery type & Uterine & Carotid & Mesenteric & Pulmonary & Renal & $\begin{array}{l}\text { Middle } \\
\text { cerebral }\end{array}$ & $\begin{array}{l}\text { Septal } \\
\text { coronary }\end{array}$ \\
\hline $\begin{array}{l}\text { Contractile agent } \\
n \\
\mathrm{pEC}_{50} \\
\mathrm{E}_{\max }(\% \text { of } \mathrm{AWT})\end{array}$ & $\begin{array}{l}\text { Phenylephrine } \\
10 \\
5 \cdot 78 \pm 0 \cdot 03 \\
100 \pm 2\end{array}$ & $\begin{array}{l}\text { Phenylephrine } \\
9 \\
6 \cdot 57 \pm 0 \cdot 52 \\
99 \pm 12\end{array}$ & $\begin{array}{l}\text { Phenylephrine } \\
10 \\
6 \cdot 07 \pm 0 \cdot 04 \\
105 \pm 2\end{array}$ & $\begin{array}{l}\text { Phenylephrine } \\
6 \\
5 \cdot 98 \pm 0 \cdot 36 \\
56 \pm 13\end{array}$ & $\begin{array}{l}\text { Phenylephrine } \\
10 \\
6 \cdot 11 \pm 0 \cdot 02 \\
109 \pm 2\end{array}$ & $\begin{array}{l}\text { Serotonin } \\
9 \\
7 \cdot 14 \pm 0 \cdot 13 \\
81 \pm 5\end{array}$ & $\begin{array}{l}\text { Serotonin } \\
7 \\
6 \cdot 56 \pm 0 \cdot 10 \\
121 \pm 16\end{array}$ \\
\hline$n$ & 21 & 19 & 17 & 6 & 18 & 18 & 15 \\
\hline $\begin{array}{l}\text { Percentage of contrac- } \\
\text { tion before ACh }\end{array}$ & $85 \pm 3$ & $69 \pm 4$ & $92 \pm 3$ & $65 \pm 8$ & $80 \pm 5$ & $66 \pm 4$ & $95 \pm 8$ \\
\hline $\begin{array}{l}\text { Percentage of } \\
\quad \text { relaxation to ACh }\end{array}$ & $47 \pm 4$ & $57 \pm 6$ & $83 \pm 4$ & $80 \pm 8$ & $59 \pm 5$ & $22 \pm 3$ & $63 \pm 7$ \\
\hline$n$ & 10 & 8 & 10 & 6 & 10 & 9 & 6 \\
\hline $\begin{array}{l}\mathrm{SNP}\left(\mathrm{pEC} \mathrm{C}_{50}\right) \\
\mathrm{E}_{\max }(\%)\end{array}$ & $\begin{array}{l}7 \cdot 30 \pm 0 \cdot 04 \\
79 \pm 4\end{array}$ & $\begin{array}{l}8 \cdot 13 \pm 0 \cdot 03^{*} \\
99 \pm 1^{*}\end{array}$ & $\begin{array}{l}6 \cdot 92 \pm 0 \cdot 07 \\
83 \pm 4\end{array}$ & $\begin{array}{l}7 \cdot 17 \pm 0 \cdot 08 \\
83 \pm 11\end{array}$ & $\begin{array}{l}6 \cdot 91 \pm 0 \cdot 08^{*} \\
65 \pm 4\end{array}$ & $\begin{array}{l}6 \cdot 50 \pm 0 \cdot 10^{*} \\
77 \pm 5\end{array}$ & $\begin{array}{l}7 \cdot 62 \pm 0 \cdot 08^{*} \\
99 \pm 1^{*}\end{array}$ \\
\hline
\end{tabular}

ACh, acetylcholine; SNP, sodium nitroprusside; NO, nitric oxide; AWT, active wall tension; $n$, number of experiments. ${ }^{*} P<0 \cdot 05$ vs uterine. 
Table 3 Vasorelaxing properties (sensitivity and maximal relaxing responses) of $E_{2}$ compared with $E_{4}$ in isolated and endothelium-intact rat uterine, aorta, carotid, and mesenteric (fourth-order) arteries. Arteries were contracted with the appropriate contractile agent before application of the estrogenic compound. The contraction before application of $E_{4}$ or $E_{2}$ is expressed as percentage of the contraction in response to $10 \mu \mathrm{mol} / \mathrm{I} \mathrm{NE}$. The sensitivity $\left(\mathrm{pEC}_{50}\right)$ of $\mathrm{E}_{4}$ or $\mathrm{E}_{2}$ is calculated with GraphPad Prism Software as described in the Materials and Methods section and denotes the negative logarithmic concentration of $\mathrm{E}_{4}$ or $\mathrm{E}_{2}$ that induces $50 \%$ relaxation compared with the maximal relaxation $\left(E_{m a x}\right)$. Potency of $E_{2}$ over $E_{4}$ is calculated as $10(p E C 50(E 2)-p E C 50(E 4))$ from paired arteries only. Values are shown as mean \pm s.E.M.

\begin{tabular}{|c|c|c|c|c|c|c|c|c|}
\hline \multirow[b]{2}{*}{ Artery type } & \multicolumn{2}{|c|}{ Uterine } & \multicolumn{2}{|c|}{ Aorta } & \multicolumn{2}{|c|}{ Carotid } & \multicolumn{2}{|c|}{ Mesenteric } \\
\hline & $E_{2}$ & $\mathrm{E}_{4}$ & $E_{2}$ & $\mathrm{E}_{4}$ & $E_{2}$ & $\mathrm{E}_{4}$ & $\mathrm{E}_{2}$ & $\mathrm{E}_{4}$ \\
\hline Control (\%) & $100 \pm 4$ & $95 \pm 3$ & $95 \pm 11$ & $96 \pm 10$ & $101 \pm 7$ & $97 \pm 7$ & $89 \pm 3$ & $92 \pm 2$ \\
\hline $\mathrm{pEC}_{50}$ & $5 \cdot 44 \pm 0 \cdot 05$ & $4 \cdot 36 \pm 0.07^{*}$ & $4 \cdot 61 \pm 0 \cdot 08$ & $4 \cdot 30 \pm 0 \cdot 15$ & $4 \cdot 91 \pm 0 \cdot 05$ & $4 \cdot 39 \pm 0 \cdot 15^{*}$ & $5 \cdot 78 \pm 0 \cdot 13$ & $4 \cdot 62 \pm 0.08^{*}$ \\
\hline $\mathrm{E}_{\max }(\%)$ & $93 \pm 1$ & $74 \pm 4^{*}$ & $59 \pm 7$ & $68 \pm 8$ & $62 \pm 4$ & $65 \pm 6$ & $99 \pm 1$ & $91 \pm 3$ \\
\hline Potency (fold) & $14 \pm 2$ & & $2 \pm 1$ & & $5 \pm 2$ & & $18 \pm 4$ & \\
\hline$n$ & 16 & 16 & 6 & 6 & 10 & 10 & 8 & 8 \\
\hline
\end{tabular}

$E_{2}, 17 \beta$-estradiol; $E_{4}$, estetrol; $N E$, norepinephrine; $n$, number of experiments. ${ }^{*} P<0 \cdot 05$ vs $E_{2}$.

Role of ERs in uterine and carotid arterial relaxing responses to $E_{4}$

To study the contributions of ER subtypes $\alpha$ and $\beta$ in relaxing responses in uterine arteries, selective agonists for ER $\alpha$ and $\mathrm{ER} \beta$ were first tested. $\mathrm{pEC}_{50}$ values for the $\mathrm{ER} \alpha$ agonist PPT were significantly greater than those for the ER $\beta$ agonist DPN $(5 \cdot 43 \pm 0 \cdot 10$ vs $4 \cdot 77 \pm 0 \cdot 25$ respectively; Fig. $2 \mathrm{~A})$.

The nonselective ER blocker ICI 182780 (1 $\mu \mathrm{mol} / \mathrm{l})$ resulted in significant rightward shifts in the CRCs to $\mathrm{E}_{4}$ and $\mathrm{E}_{2}$ in uterine (Fig. 2B) arteries. For $\mathrm{E}_{4}, \mathrm{pEC}_{50}$ averaged $4 \cdot 54 \pm 0 \cdot 08$ in vehicle and $4 \cdot 05 \pm 0 \cdot 11$ in ICI 182780 -treated uterine arteries (Fig. 2B). For $\mathrm{E}_{2}, \mathrm{pEC}_{50}$ averaged $5 \cdot 56 \pm 0 \cdot 07$ in vehicle and $5 \cdot 12 \pm 0 \cdot 05$ in ICI 182780 -treated uterine arteries (Fig. 2B).

Role of endothelium-derived relaxing factors in uterine arterial relaxing responses to $E_{4}$

The cyclooxygenase inhibitor INDO $(10 \mu \mathrm{mol} / \mathrm{l})$ did not significantly alter sensitivity to $\mathrm{E}_{4}$ or $\mathrm{E}_{2}$ (Fig. $3 \mathrm{~A}$ ). The $\mathrm{NO}$ synthase blocker L-NAME $(100 \mu \mathrm{mol} / \mathrm{l})$ caused a significant rightward shift in the $\mathrm{CRC}$ to $\mathrm{E}_{2}$, but not to $\mathrm{E}_{4}$ (Fig. $3 \mathrm{~B}$ ).
The same trend as with L-NAME alone was observed when uterine arteries were incubated with both L-NAME and INDO (Fig. 3C). We next tested the role of cGMP in mediating the response to $\mathrm{E}_{4}$ and $\mathrm{E}_{2}$ by preventing $\mathrm{NO}$ release and action by blocking the sGC with ODQ $(10 \mu \mathrm{mol} / \mathrm{l})$ in combination with L-NAME and INDO. Interestingly, blockade of cGMP release blunted the response to $\mathrm{E}_{4}$ but not to $E_{2}$ (Fig. 3D). The role of EDHF in mediating relaxing responses was pharmacologically tested by the addition of TRAM-34 (1 $\mu \mathrm{mol} / \mathrm{l})$ and UCL 1684 (1 $\mu \mathrm{mol} / \mathrm{l})$, inhibitors of $\mathrm{SK}_{\mathrm{Ca}}$ and $\mathrm{IK}_{\mathrm{Ca}}$ respectively. Inhibition of $\mathrm{SK}_{\mathrm{Ca}}$ and $\mathrm{IK}_{\mathrm{Ca}}$ channels in the combined presence of L-NAME and INDO did not alter the response to $\mathrm{E}_{4}$ or $\mathrm{E}_{2}$ (Fig. 3E).

The contribution of the endothelium to relaxing responses to $E_{4}$ was assessed by mechanical removal of the endothelium. Successful denudation was confirmed by the absence of relaxation to $1 \mu \mathrm{M}$ ACh in PHE-contracted arteries $(0 \pm 1 \%)$. A significant rightward shift in the CRCs to $E_{4}$ and $E_{2}$ was observed in endothelium-denuded compared with endothelium-intact uterine arteries (Fig. 3F). Table 5 summarizes the effects of pharmacological inhibitors and endothelial denudation on the vasodilator properties of $\mathrm{E}_{4}$ compared with $\mathrm{E}_{2}$ in rat uterine arteries.

Table 4 Vasorelaxing properties (sensitivity and maximal relaxing responses) of $E_{2}$ compared to $E_{4}$ in isolated and endothelium-intact rat pulmonary, renal, middle cerebral, and septal coronary arteries. Arteries were contracted with the appropriate contractile agent before application of the estrogenic compound. The contraction before application of $E_{4}$ or $E_{2}$ is expressed as percentage of the contraction in response to $10 \mu \mathrm{mol} / \mathrm{I} \mathrm{NE}$. The sensitivity $\left(\mathrm{pEC}_{50}\right)$ of $\mathrm{E}_{4}$ or $\mathrm{E}_{2}$ is calculated with GraphPad Prism Software as described in the Materials and Methods section and denotes the negative logarithmic concentration of $\mathrm{E}_{4}$ or $\mathrm{E}_{2}$ that induces $50 \%$ relaxation compared to the maximal relaxation $\left(\mathrm{E}_{\max }\right)$. Potency of $\mathrm{E}_{2}$ over $\mathrm{E}_{4}$ is calculated as $10(\mathrm{pEC} 50(\mathrm{E} 2)-\mathrm{pEC50}(\mathrm{E} 4))$ from paired arteries only. Values are shown as mean \pm s.E.M.

Pulmonary

\begin{tabular}{lccc}
\cline { 2 - 3 } Artery type & $E_{2}$ & & $E_{4}$ \\
\cline { 2 - 2 } Control (\%) & $93 \pm 14$ & & $97 \pm 6$ \\
pEC $_{50}$ & $5 \cdot 60 \pm 0 \cdot 09$ & & $4 \cdot 35 \pm 0 \cdot 06^{*}$ \\
$E_{\max }(\%)$ & $99 \pm 1$ & & $80 \pm 8$ \\
Potency (fold) & $20 \pm 6$ & & \\
$n$ & 4 &
\end{tabular}

Renal

\begin{tabular}{ccc}
\hline$E_{2}$ & & $E_{4}$ \\
\cline { 1 - 1 } $81 \pm 2$ & & $84 \pm 3$ \\
$5 \cdot 25 \pm 0 \cdot 11$ & & $4 \cdot 30 \pm 0 \cdot 05^{*}$ \\
$81 \pm 2$ & & $66 \pm 4^{*}$ \\
$11 \pm 3$ & & \\
8 & 8
\end{tabular}

Middle cerebral

\begin{tabular}{c}
\hline$E_{2}$ \\
\hline $77 \pm 6$ \\
$5 \cdot 49 \pm 0 \cdot 07$ \\
$97 \pm 1$ \\
$22 \pm 5$ \\
8
\end{tabular}

Septal coronary

\begin{tabular}{|c|c|}
\hline$E_{2}$ & $\mathrm{E}_{4}$ \\
\hline $94 \pm 5$ & $99 \pm 12$ \\
\hline $5 \cdot 68 \pm 0 \cdot 10$ & $4 \cdot 74 \pm 0 \cdot 0$ \\
\hline $100 \pm 0$ & $98 \pm 2$ \\
\hline $10 \pm 2$ & \\
\hline 4 & 4 \\
\hline
\end{tabular}

$E_{2}, 17 \beta$-estradiol; $E_{4}$, estetrol; $N E$, norepinephrine; $n$, number of experiments. ${ }^{*} P<0.05$ vs $E_{2}$. 
A Uterine artery

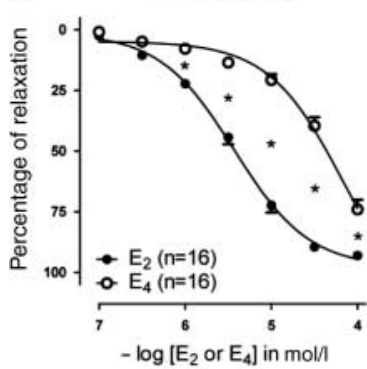

C Carotid artery

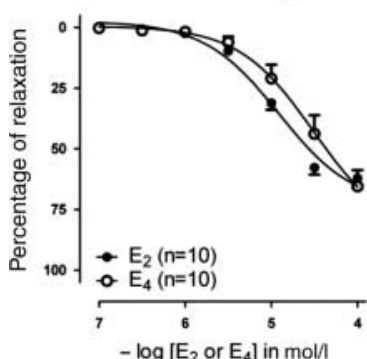

E Pulmonary artery

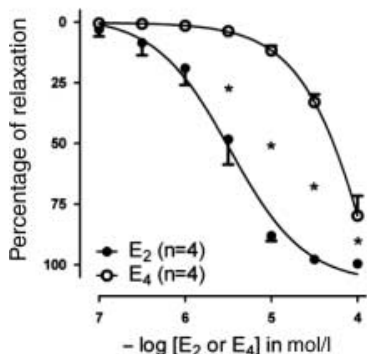

G Middle cerebral artery

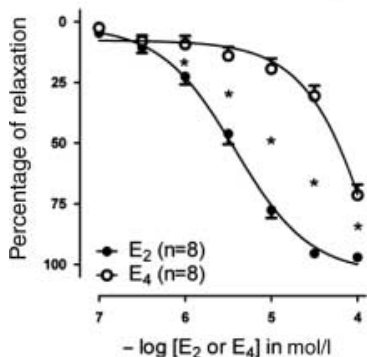

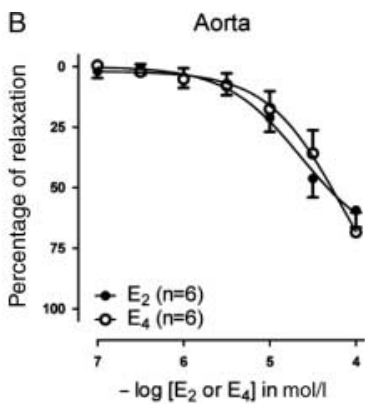
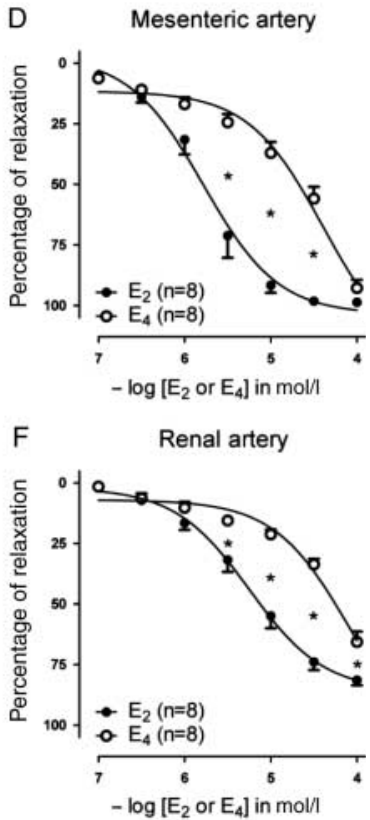

$\mathrm{H}$ Septal coronary artery

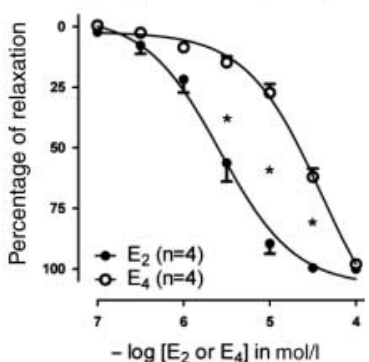

$-\log \left[E_{2}\right.$ or $\left.E_{4}\right]$ in $\mathrm{mol} / \mathrm{l}$

Figure 1 Relaxing responses to $17 \beta$-estradiol $\left(E_{2} ; 0 \cdot 1-100 \mu \mathrm{mol} / \mathrm{l}\right.$; closed circles) and estetrol ( $\mathrm{E}_{4} ; 0 \cdot 1-100 \mu \mathrm{mol} / /$; open circles) in contracted uterine $(A)$, aorta $(B)$, carotid $(C)$, fourth-order mesenteric (D), pulmonary $(\mathrm{E})$, renal $(\mathrm{F})$, middle cerebral $(\mathrm{G})$, and septal coronary $(\mathrm{H})$ arteries. Values are expressed as mean \pm S.E.M. ${ }^{*} P<0 \cdot 05$ vs $E_{2}$.

\section{Inhibition of calcium entry by $E_{4}$ in $K^{+}$-depolarized uterine arteries}

From Fig. 3F, it is clear that there is a significant endotheliumindependent relaxation response to both $\mathrm{E}_{4}$ and $\mathrm{E}_{2}$. We therefore analyzed whether $\mathrm{E}_{4}$ could inhibit the entry of $\mathrm{Ca}^{2+}$ via voltage-operated $\mathrm{Ca}^{2+}$ channels on smooth muscle

cells. Uterine arteries were first depleted of intracellular $\mathrm{Ca}^{2+}$ by washing them three times with $60 \mathrm{mmol} / \mathrm{Ca}^{2+}$-free $\mathrm{K}^{+}$ $\mathrm{KRB}$, followed by the addition of either vehicle (ethanol), or three different concentrations of $\mathrm{E}_{4}$ or $\mathrm{E}_{2}$. Cumulative addition of $\mathrm{CaCl}_{2}$ resulted in a contraction that was not significantly blocked by the lowest concentrations tested, namely $10 \mu \mathrm{mol} / 1 \mathrm{E}_{4}$ (Fig. 4A) and $3 \mu \mathrm{mol} / 1 \mathrm{E}_{2}$ (Fig. 4B). Next, we compared the inhibitory effects of higher concentrations of $E_{4}(30$ and $100 \mu \mathrm{mol} / \mathrm{l})$ and $E_{2}$ (10 and $30 \mu \mathrm{mol} / \mathrm{l})$. A concentration-dependent inhibitory effect of both $\mathrm{E}_{4}$ and $\mathrm{E}_{2}$ was observed. Overall, the results in Fig. 4 show that $\mathrm{E}_{4}$ has tenfold lower potency than $\mathrm{E}_{2}$ in inhibiting $\mathrm{Ca}^{2+}$ entry in depolarized smooth muscle cells.

\section{Discussion}

This study assessed the ex vivo relaxing potency of the steroid hormone $\mathrm{E}_{4}$ in comparison to $\mathrm{E}_{2}$ in eight arterial beds, i.e. uterine artery, thoracic aorta, the left common carotid artery, the fourth-order branch of the superior mesenteric artery, pulmonary artery, left main renal artery, middle cerebral artery, and septal coronary artery of the rat. In all arteries tested, $\mathrm{E}_{4}$ had a weaker relaxing potency than $\mathrm{E}_{2}$. Pharmacological blockade experiments revealed that $\mathrm{E}_{4}$ caused relaxation of precontracted rat uterine arteries via both an endothelium-dependent (involving ER) and an ODQ-sensitive mechanism. Furthermore, $\mathrm{E}_{4}$ inhibited smooth muscle cell $\mathrm{Ca}^{2+}$ entry and contraction, albeit with tenfold lower potency than $\mathrm{E}_{2}$.

Estrogens exert their biological effects by binding to specific ERs, primarily $\mathrm{ER} \alpha$ and $\mathrm{ER} \beta$. Previous in vitro binding studies showed that $\mathrm{E}_{4}$ has moderate affinity for human ERs, with four to five times higher affinity for the ER $\alpha$ compared with the ER $\beta$ (Visser et al. 2008). The same study reported that $\mathrm{E}_{4}$ has tenfold lower affinity for the $\mathrm{ER} \alpha$
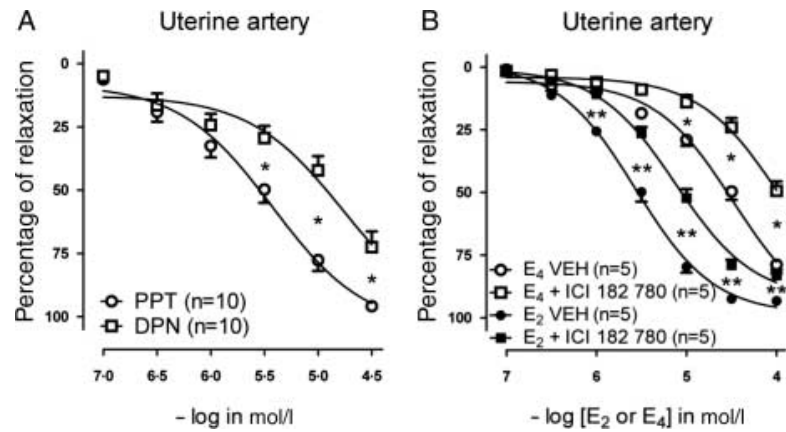

Figure 2 Relaxing responses to the ER $\alpha$ agonist PPT $(0 \cdot 1-30 \mu \mathrm{mol} / \mathrm{l}$; circles) and the ER $\beta$ agonist DPN $(0 \cdot 1-30 \mu \mathrm{mol} / \mathrm{l}$; squares) in $\mathrm{PHE}$-contracted uterine arteries (A). Relaxing responses to $17 \beta$-estradiol ( $E_{2} ; 0 \cdot 1-100 \mu \mathrm{mol} / \mathrm{l}$; closed symbols) and estetrol $\left(\mathrm{E}_{4} ; 0 \cdot 1-100 \mu \mathrm{mol} / \mathrm{l}\right.$; open symbols) in PHE-contracted uterine arteries in the presence of the nonselective estrogen receptor blocker ICI $182780(1 \mu \mathrm{mol} / \mathrm{l})$ or the absence of ICI 182780 $(\mathrm{VEH} ; 10 \mu \mathrm{l}$ DMSO; B). Values are expressed as mean \pm S.E.M. ${ }^{*} P<0 \cdot 05$ vs PPT (A). ${ }^{*} P<0 \cdot 05$ vs $\mathrm{E}_{4} \mathrm{VEH} ;{ }^{* *} P<0 \cdot 05$ vs $\mathrm{E}_{2} \mathrm{VEH}(\mathrm{B})$. 
A
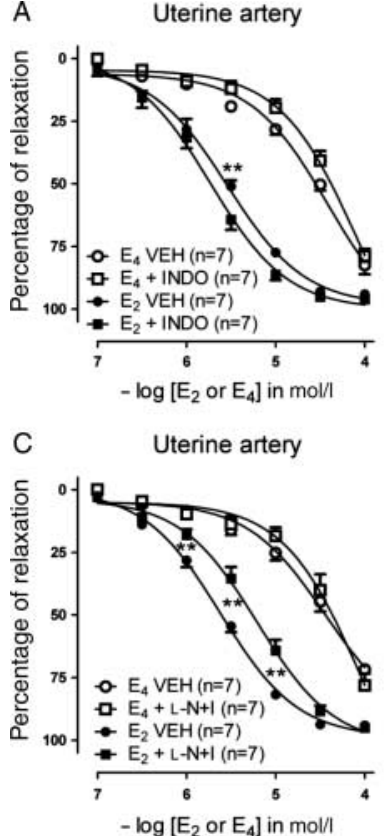

$E$

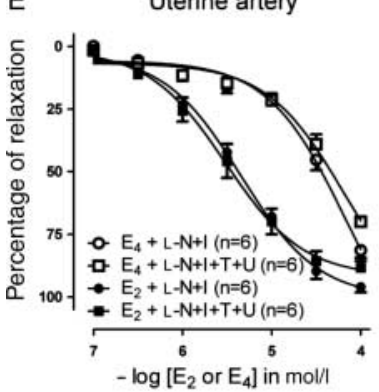

B

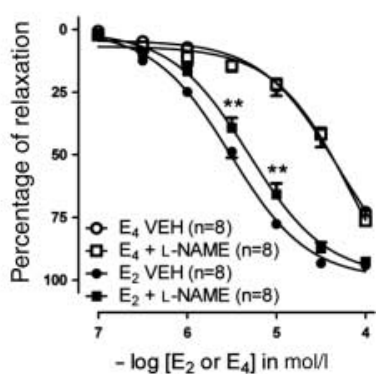

D

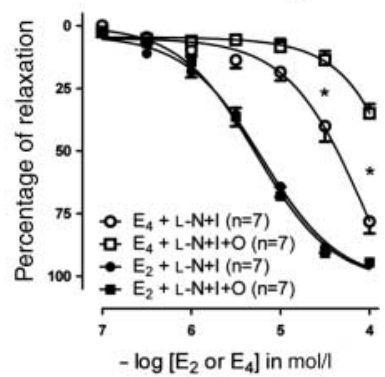

$\mathrm{F}$

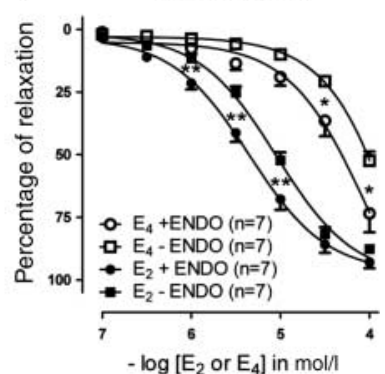

Figure 3 Relaxing responses to $17 \beta$-estradiol $\left(E_{2} ; 0 \cdot 1-100 \mu \mathrm{mol} / \mathrm{l}\right.$; closed symbols) and estetrol ( $\mathrm{E}_{4} ; 0 \cdot 1-100 \mu \mathrm{mol} / \mathrm{l}$; open symbols) in $\mathrm{PHE}-\mathrm{contracted}$ uterine arteries in the absence of any pharmacological inhibitor $(\mathrm{VEH})$, in the presence of the cyclooxygenase inhibitor INDO (10 $\mu \mathrm{mol} / \mathrm{l}$; A); the NO synthase blocker L-NAME $(100 \mu \mathrm{mol} / \mathrm{l} ; \mathrm{B})$; the combined presence of L-NAME and INDO $(\mathrm{L}-\mathrm{N}+\mathrm{I} ; \mathrm{C})$, the combined presence of $\mathrm{L}-\mathrm{NAME}, \mathrm{INDO}$, and the selective sGC blocker ODQ $(10 \mu \mathrm{mol} / \mathrm{l} ; \mathrm{L}-\mathrm{N}+\mathrm{I}+\mathrm{O}$; D); the combined presence of L-NAME, INDO, and the selective $\mathrm{IK}_{\mathrm{Ca}}$ channel blocker TRAM-34 $(1 \mu \mathrm{mol} / \mathrm{l})$ and the selective $\mathrm{SK}_{\mathrm{Ca}}$ channel blocker UCL $1684(1 \mu \mathrm{mol} / \mathrm{l} ; \mathrm{E})$; and in the presence $(+$ ENDO) and absence ( - ENDO) of endothelium (F). Values are expressed as mean \pm s.E.M. ${ }^{*} P<0.05$ vs $\mathrm{E}_{4} \mathrm{VEH} ;{ }^{* *} P<0.05$ vs $\mathrm{E}_{2} \mathrm{VEH}$.

compared with the reference compound diethylstilbestrol (DES) and 100-fold lower affinity for the ER $\beta$ compared with DES (Visser et al. 2008). Kitazawa et al. (1997) showed that DES has threefold higher potency than $\mathrm{E}_{2}$ in relaxing rat femoral arteries. Based on these observations, it was postulated that $\mathrm{E}_{4}$ would have weaker vasorelaxant potency than $E_{2}$. The current ex vivo arterial reactivity study clearly showed that this is indeed the case for a broad spectrum of rat artery types. $\mathrm{E}_{4}$ was a much weaker $(\sim 14$-fold $)$ vasorelaxant than $E_{2}$ in

PHE-contracted endothelium-intact uterine arteries in the absence of any pharmacological inhibitor. Thus, substitution of two hydrogen atoms for two hydroxyl groups on the carbon 15 and 16 positions of the $\mathrm{E}_{2}$ molecule appears to result in lower receptor affinity and a reduced functional response.

In smaller resistance arteries, e.g. the middle cerebral artery and fourth-order mesenteric artery, $\mathrm{E}_{4}$ was an even weaker vasorelaxant compared with $\mathrm{E}_{2}$. Surprisingly, in larger elastic arteries, such as the thoracic aorta and common carotid artery, the difference in potency between $\mathrm{E}_{4}$ and $\mathrm{E}_{2}$ was smaller, mainly because of a reduction in sensitivity to $E_{2}$ compared with its sensitivity in smaller arteries. This reduced sensitivity to $E_{2}$ in larger arteries is in agreement with findings of others (Lindsey et al. 2011). Furthermore, the differential sensitivities to $E_{2}$ of the mesenteric, renal, and uterine arteries observed in this study are similar to values reported by others (Naderali et al. 1999, Leung et al. 2005, Scott et al. 2007). Scott et al. observed a $\mathrm{pEC}_{50}$ value of $5.47 \pm 0.05$ in endotheliumdenuded uterine arteries, while Naderali et al. observed a $\mathrm{pEC}_{50}$ value of $6.04 \pm 0.06$ in the superior mesenteric artery, and Leung et al. (2005) observed a $\mathrm{pEC}_{50}$ value of $5 \cdot 54 \pm 0 \cdot 22$ in the renal artery. Hence, great inter-arterial variability exists in vasomotor responses to estrogenic hormones.

Previous studies have shown that in vivo administration of the nonselective ER antagonist ICI 182780 into one uterine artery of ovariectomized and $\mathrm{E}_{2}$-treated nonpregnant sheep blunted the $\mathrm{E}_{2}$ effect on uterine blood flow, confirming its ER dependence (Magness et al. 2005). Here, we show that ICI 182780 resulted in a significant rightward shift in the CRCs to $E_{4}$ and $E_{2}$, suggesting the contribution of ER. However, $\mathrm{E}_{2}$-mediated relaxing responses were not inhibited by ICI 182780 in endothelium-denuded rat uterine arteries (Scott et al. 2007), most likely because the endothelial layer, which expresses ERs, had been mechanically removed. In vitro studies showed that $\mathrm{ER} \alpha$ are localized in caveolae in isolated endothelial cells (Chambliss et al. 2000), supporting the conclusion that the lack of inhibitory effect of ICI 182780 in denuded uterine arteries was due to the mechanical removal of the endothelial layer.

We compared relaxing responses to $E_{4}$ and $E_{2}$ with responses to selective agonists for $\operatorname{ER} \alpha$ and $\operatorname{ER} \beta$ in uterine arteries. We showed that the ER $\alpha$ agonist PPT has a more potent relaxing effect on uterine arteries compared with the ER $\beta$ agonist DPN. This finding is consistent with the study by Montgomory et al. (2003) in which the relative potency of PPT was greater than DPN in relaxing rat mesenteric arteries ex vivo. The order of potency of the estrogenic compounds and ER agonists in relaxing the rat uterine artery is $\mathrm{E}_{2}=\mathrm{PPT}>\mathrm{DPN}>\mathrm{E}_{4}$.

The current study demonstrated that the relaxing action of $\mathrm{E}_{4}$ in uterine arteries was L-NAME insensitive, suggesting that endothelium-derived NO plays a marginal role in $\mathrm{E}_{4}$-mediated relaxing responses in the rat uterine vasculature. By contrast, relaxing responses to $\mathrm{E}_{2}$ were partially L-NAME sensitive in rat uterine arteries, similar to earlier observations 
Table 5 Influence of pharmacological inhibitors and endothelial denudation on the vasodilator properties of $E_{2}$ compared with $E_{4}$ in rat uterine arteries. The sensitivity $\left(\mathrm{pEC}_{50}\right.$ ) of $\mathrm{E}_{4}$ or $\mathrm{E}_{2}$ is calculated with GraphPad Prism Software as described in the Materials and Methods section and denotes the negative logarithmic concentration of $E_{4}$ or $E_{2}$ that induces $50 \%$ relaxation compared to the maximal relaxation $\left(E_{\max }\right)$. See text for inhibitor concentrations used. When more arteries of the same type were isolated from one rat, the values were averaged and regarded as $n=1$ per rat. Values are shown as mean \pm S.E.M.

\section{Treatment}

Control (none)

ICI 182780

Indomethacin (INDO)

$N^{\omega}$-nitro-L-arginine methyl ester (L-NAME)

L-NAME + INDO

$\mathrm{L}-\mathrm{NAME}+\mathrm{INDO}+\mathrm{ODQ}$

L-NAME + INDO+TRAM-34 + UCL 1684

Endothelial denudation
$\mathbf{E}_{2}$

\begin{tabular}{|c|c|c|}
\hline $\mathrm{pEC}_{50}$ & $\mathrm{E}_{\max }(\%)$ & $n$ \\
\hline $5 \cdot 69 \pm 0 \cdot 10$ & $94 \pm 1$ & 9 \\
\hline $5 \cdot 12 \pm 0.05^{*}$ & $83 \pm 2 *$ & 5 \\
\hline $5 \cdot 75 \pm 0 \cdot 07$ & $96 \pm 1$ & 7 \\
\hline $5 \cdot 32 \pm 0.08^{*}$ & $93 \pm 1$ & 8 \\
\hline $5 \cdot 26 \pm 0.09 *$ & $95 \pm 2$ & 7 \\
\hline $5 \cdot 34 \pm 0.05^{*}$ & $94 \pm 1$ & 9 \\
\hline $5 \cdot 53 \pm 0 \cdot 11$ & $88 \pm 4$ & 6 \\
\hline $5 \cdot 07 \pm 0 \cdot 06^{*}$ & $89 \pm 1$ & 7 \\
\hline
\end{tabular}

$\mathbf{E}_{4}$

\begin{tabular}{|c|c|}
\hline $\mathrm{pEC}_{50}$ & $\mathrm{E}_{\max }(\%)$ \\
\hline $4 \cdot 66 \pm 0 \cdot 15^{+}$ & $75 \pm 3^{+}$ \\
\hline $4 \cdot 05 \pm 0 \cdot 11^{*,+}$ & $49 \pm 4^{*,+}$ \\
\hline $4 \cdot 40 \pm 0 \cdot 06^{\dagger}$ & $79 \pm 3^{+}$ \\
\hline $4 \cdot 39 \pm 0 \cdot 06^{+}$ & $76 \pm 4^{+}$ \\
\hline $4 \cdot 43 \pm 0 \cdot 10^{\dagger}$ & $78 \pm 5$ \\
\hline $3 \cdot 68 \pm 0 \cdot 08^{*,+}$ & $35 \pm 4^{*,+}$ \\
\hline $4 \cdot 33 \pm 0.08^{+}$ & $70 \pm 2^{+}$ \\
\hline $3 \cdot 96 \pm 0.05^{*,+}$ & $52 \pm 4^{*,+}$ \\
\hline
\end{tabular}

$\mathrm{E}_{2}, 17 \beta$-estradiol; $\mathrm{E}_{4}$, estetrol; $n$, number of experiments. ${ }^{*} P<0 \cdot 05$ vs control, ${ }^{+} P<0 \cdot 05$ vs $\mathrm{E}_{2}$.

in the in vivo uterine circulation (Van Buren et al. 1992, Rosenfeld et al. 1996). Our data do not provide a clear mechanistic explanation for the L-NAME insensitivity of the uterine arterial relaxing responses to $\mathrm{E}_{4}$. Neither prostacyclin $\left(\mathrm{PGI}_{2}\right)$ nor EDHF contributed to the relaxing response to either estrogenic hormone. Surprisingly, pharmacological inhibition of $\mathrm{sGC}$ resulted in marked blunting of $\mathrm{E}_{4}$-mediated relaxation in uterine arteries, an effort that was not observed in $\mathrm{E}_{2}$-treated vessels.

Both NO synthase and large-conductance $\mathrm{Ca}^{2+}$-activated $\mathrm{K}^{+}$channels $\left(\mathrm{BK}_{\mathrm{Ca}}\right)$ are involved in acute $\mathrm{E}_{2}$-induced vasodilation in oophorectomized nonpregnant ewes (Khan et al. 2000, Rosenfeld et al. 2000). NO activates cGMPdependent protein kinase $\mathrm{G}$, which subsequently opens $\mathrm{BK}_{\mathrm{Ca}}$ on smooth muscle cells, thus decreasing $\mathrm{Ca}^{2+}$ influx via voltage-gated $\mathrm{Ca}^{2+}$ channels, leading to hyperpolarization and relaxation. A more detailed mechanistic study is needed to determine directly whether $\mathrm{E}_{4}$ can induce the release of cGMP from smooth muscle cells or whether L-NAMEinsensitive intracellular NO stores play a role. Endothelial denudation blunted relaxations to $\mathrm{E}_{4}$ and $\mathrm{E}_{2}$ in the uterine artery, probably by disrupting the ER in caveolae on the plasma membrane of endothelial cells.

Both $E_{4}$ and $E_{2}$ elicited large endothelium-independent relaxation responses, suggesting that estrogenic compounds may interfere with excitation-contraction coupling, thus inhibiting contraction. Excitatory agonists, such as adrenergic agonists and contractile peptides like angiotensin II, can stimulate smooth muscle contraction through three distinct signaling pathways: $\mathrm{Ca}^{2+}$ influx through membrane $\mathrm{Ca}^{2+}$ channels, $\mathrm{IP}_{3}$-induced $\mathrm{Ca}^{2+}$ release from the sarcoplasmatic reticulum, and $\mathrm{Ca}^{2+}$ sensitizing mechanisms of the contractile machinery (Somlyo \& Somlyo 1994, Hilgers \& Webb 2005). The contraction-modulating effects of estrogens have been attributed to their $\mathrm{Ca}^{2+}$ antagonistic properties. $\mathrm{E}_{2}$ can inhibit voltage-dependent calcium inward currents (L-type voltage-operated $\mathrm{Ca}^{2+}$ channels or L-VOCC) located on smooth muscle cells, but not on endothelial cells (Shan et al.
1994, Zhang et al. 1994, Nakajima et al. 1995). This leads to reduced intracellular $\mathrm{Ca}^{2+}$ concentration and subsequent lower $\mathrm{Ca}^{2+}$-calmodulin-dependent myosin light-chain phosphorylation and contraction. By contrast, $\mathrm{E}_{2}$ effects have not been ascribed to modulating $\mathrm{Ca}^{2+}$ release from intracellular stores or by $\mathrm{IP}_{3}$ (Kitazawa et al. 1997). High $\mathrm{K}^{+}$ concentrations $(>25 \mathrm{mmol} / \mathrm{l})$ can depolarize the smooth muscle cell membrane and stimulate L-VOCC and $\mathrm{Ca}^{2+}$ influx independent of the endothelium. In $\mathrm{Ca}^{2+}$-free conditions, no contraction can occur during high $\mathrm{K}^{+}$ $(60 \mathrm{mmol} / \mathrm{l})$ depolarization. Titration of $\mathrm{CaCl}_{2}$ into the organ bath results in a $\mathrm{Ca}^{2+}$-dependent contraction. Using this approach in endothelium-intact uterine arteries, in conditions where NO release and action were blocked, we tested the $\mathrm{Ca}^{2+}$ antagonistic effects of $\mathrm{E}_{4}$ and found that $\mathrm{E}_{4}$ and $\mathrm{E}_{2}$ concentration-dependently blocked L-VOCCdependent contractions in uterine arteries. $\mathrm{E}_{4}$ was roughly
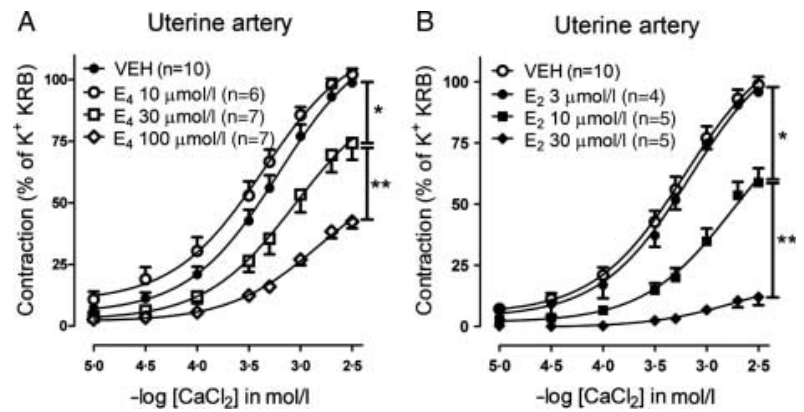

Figure 4 Contractile responses to cumulative addition of calcium chloride $\left(\mathrm{CaCl}_{2} ; 0 \cdot 01-2 \cdot 5 \mathrm{mmol} / \mathrm{l}\right)$ during $60 \mathrm{mmol} / \mathrm{l} \mathrm{K} \mathrm{K}^{+}$depolarization in uterine arteries that were incubated with L-NAME $(100 \mu \mathrm{mol} / \mathrm{l})$ and INDO $(10 \mu \mathrm{mol} / \mathrm{l})$. (A) Effects of $10 \mu \mathrm{mol} / \mathrm{l}$ estetrol ( $\mathrm{E}_{4}$; open circles), $30 \mu \mathrm{mol} / / \mathrm{E}_{4}$ (open squares), and $100 \mu \mathrm{mol} / \mathrm{I}_{4}$ (open diamonds) compared to vehicle (VEH; closed circles). (B) Effects of $3 \mu \mathrm{mol} / \mathrm{l} 17 \beta$-estradiol ( $E_{2}$; closed circles), $10 \mu \mathrm{mol} / \mathrm{I} \mathrm{E}_{2}$ (closed squares), and $30 \mu \mathrm{mol} / \mathrm{I} \mathrm{E}_{2}$ (closed diamonds) compared to vehicle (VEH; open circles). $\mathrm{E}_{4}$ or $\mathrm{E}_{2}$ was applied 10 min before the cumulative application of $\mathrm{CaCl}_{2}$. Values are expressed as mean + s.E.M. ${ }^{*} P<0 \cdot 05$ vs VEH; $* * P<0 \cdot 05$ 
tenfold less potent than $\mathrm{E}_{2}$ in inhibiting these contractions. Interestingly, $3 \mu \mathrm{mol} / 1 \mathrm{E}_{2}$ did not block L-VOCC-dependent contractions (Fig. 4A), but resulted in $\sim 50 \%$ relaxation of PHE-contracted uterine arteries (Fig. 1A). The fact that these $\mathrm{Ca}^{2+}$ antagonistic effects of $\mathrm{E}_{4}$ and $\mathrm{E}_{2}$ are seen at higher concentrations might suggest that these $\mathrm{Ca}^{2+}$ antagonistic effects are unrelated to their endothelium and ER-dependent estrogenic effects.

In conclusion, we have demonstrated that $\mathrm{E}_{4}$ is capable of inducing a relaxing response in arteries from a variety of vascular beds. $E_{4}$ was several fold less potent than $E_{2}$ in relaxing these arteries, but the differential relaxing potency of $\mathrm{E}_{4}$ vs $\mathrm{E}_{2}$ decreased in larger arteries, mainly because of reduced potency of $\mathrm{E}_{2}$. $\mathrm{E}_{4}$ caused relaxation of contracted uterine arteries via an endothelium-dependent mechanism involving ERs, as well as smooth muscle-dependent inhibition of $\mathrm{Ca}^{2+}$ entry. The mechanism of the discrepancy between the micromolar range estrogenic effects on ex vivo vasorelaxation and the nanomolar range of circulating estrogen levels in vivo is unclear, but the observation does suggest that the effects of estrogens on ex vivo vasorelaxation are pharmacological in nature. The relatively low vasorelaxing potency of $\mathrm{E}_{4}$ might be beneficial in clinical use in that $\mathrm{E}_{4}$ will provide beneficial effects associated with estrogens without altering hemodynamics. Furthermore, previous studies have shown that $\mathrm{E}_{4}$ (compared with $\mathrm{E}_{2}$ ) has a low first-pass liver metabolism, no SHBG binding, ER antagonistic effects on breast cancer models, and anti-thrombotic properties, suggesting that $\mathrm{E}_{4}$ has promise for clinical use as a component hormone in a combined oral contraceptive and as therapy for breast tumors.

\section{Declaration of interest}

The authors declare that there is no conflict of interest that could be perceived as prejudicing the impartiality of the research reported.

\section{Funding}

This study was sponsored by Pantarhei Bioscience B.V. (Zeist, The Netherlands). Partial support came from RO1 grant HL087980.

\section{References}

Burnham MP, Bychkov R, Feletou M, Richards GR, Vanhoutte PM, Weston AH \& Edwards G 2002 Characterization of an apamin-sensitive small-conductance $\mathrm{Ca}^{2+}$-activated $\mathrm{K}^{+}$channel in porcine coronary artery endothelium: relevance to EDHF. British Journal of Pharmacology 135 1133-1143. (doi:10.1038/sj.bjp.0704551)

Campos Rosa J, Galanakis D, Piergentili A, Bhandari K, Ganellin CR, Dunn PM \& Jenkinson DH 2000 Synthesis, molecular modeling, and pharmacological testing of bis-quinolinium cyclophanes: potent, nonpeptidic blockers of the apamin-sensitive $\mathrm{Ca}^{2+}$-activated $\mathrm{K}^{+}$channel. Journal of Medicinal Chemistry 43 420-431. (doi:10.1021/jm9902537)

Chambliss KL, Yuhanna IS, Mineo C, Liu P, German Z, Sherman TS, Mendelsohn ME, Anderson RGW \& Shaul PW 2000 Estrogen receptor $\alpha$ and endothelial nitric oxide synthase are organized into a functional signaling module in caveolae. Circulation Research 87 e44-e52. (doi:10.1161/01.RES.87.11.e44)

Coelingh Bennink HJT, Holinka C \& Diczfalusy E 2008a Estetrol review: profile and potential clinical applications. Climacteric 11 (Suppl 1) 47-58. (doi:10.1080/13697130802073425)

Coelingh Bennink HJT, Skouby S, Bouchard P \& Holinka CF $2008 \mathrm{~b}$ Ovulation inhibition by estetrol in an in vivo model. Contraception $\mathbf{7 7}$ 186-190. (doi:10.1016/j.contraception.2007.11.014)

Coelingh Bennink HJT, Singer C, Simoncini T, Genazzani AR \& Holinka CF 2008 c Estetrol, a pregnancy-specific human steroid, prevents and suppresses mammary tumor growth in a rat model. Climacteric 11 (Suppl 1) 29. (doi:10.1080/13697130802040325)

Crane GJ, Gallagher N, Dora KA \& Garland CJ 2003 Small- and intermediate-conductance calcium-activated $\mathrm{K}^{+}$channels provide different facets of endothelium-dependent hyperpolarization in rat mesenteric arteries. Journal of Physiology 553 183-189. (doi:10.1113/jphysiol.2003. 051896)

Feher A, Ruthai I, Beleznai T, Ungvari Z, Csiszar A, Edes I \& Bagi Z 2010 Caveolin-1 limits the contribution of $\mathrm{BK}(\mathrm{Ca})$ channel to EDHF-mediated arteriolar dilation: implications in diet-induced obesity. Cardiovascular Research 87 732-739. (doi:10.1093/cvr/cvq088)

Gurpide E, Schwers J, Welch MT, Vande Wiele RL \& Lieberman S 1966 Fetal and maternal metabolism of estradiol during pregnancy. Journal of Clinical Endocrinology and Metabolism 26 1355-1365. (doi:10.1210/jcem-26-12-1355)

Hagen AA, Barr M \& Diczfalusy E 1965 Metabolism of $17 \beta$-oestradiol4-14C in early infancy. Acta Endocrinologica 49 207-220.

Hammond GL, Hogeveen KN, Visser M \& Coelingh Bennink HJT 2008 Estetrol does not bind sex hormone binding globulin or increase its production by human HepG2 cells. Climacteric 11 (Suppl 1) 41-46. (doi:10.1080/13697130701851814)

Heegaard AM, Holinka CF, Kenemans P \& Coelingh Bennink HJT 2008 Estrogenic uterovaginal effects of oral estetrol in modified Allen-Doisy test. Climacteric 11 (Suppl 1) 22-28. (doi:10.1080/13697130701842490)

Hilgers RH \& Webb RC 2005 Molecular aspects of arterial smooth muscle contraction: focus on Rho. Experimental Biology and Medicine 230 829-835.

Holinka CF, Brincat M \& Coelingh Bennink HJT 2008 Preventive effect of oral estetrol in a menopausal hot flush model. Climacteric 11 (Suppl 1) 15-21. (doi:10.1080/13697130701822807)

Khan LH, Rosenfeld CR, Liu XT \& Magness RR 2000 Regulation of the cGMP-cPKG pathway and large-conductance $\mathrm{Ca}^{2+}$-activated $\mathrm{K}^{+}$ channels in uterine arteries during the ovine ovarian cycle. American Journal of Physiology. Endocrinology and Metabolism 298 E222-E228. (doi:10.1152/ajpendo.00375.2009)

Killam AP, Rosenfeld CR, Battaglia FC, Makowski EL \& Meschia G 1973 Effect of estrogens on the uterine blood flow of oophorectomized ewes. American Journal of Obstetrics and Gynecology 115 1045-1052.

Kitazawa T, Hamada E, Kitazawa K \& Gaznabi AKM 1997 Non-genomic mechanism of $17 \beta$-oestradiol-induced inhibition of contraction in mammalian vascular smooth muscle. Journal of Physiology 499 497-511.

Leung FP, Yao X, Lan CW, Ko WW, Lu L \& Huang Y 2005 Raloxifene relaxes rat intrarenal arteries by inhibiting $\mathrm{Ca}^{2+}$ influx. American Journal of Physiology. Renal Physiology 289 F137-F144. (doi:10.1152/ajprenal.00353. 2004)

Levine MG, Miodovnik M \& Clark KE 1984 Uterine vascular effects of estetrol in nonpregnant ewes. American Journal of Obstetrics and Gynecology $148735-738$.

Lindsey SH, Carver KA, Prossnitz ER \& Chappell MC 2011 Vasodilation in response to the GPR 30 agonist G-1 is not different from estradiol in the mRen2.Lewis female rat. Journal of Cardiovascular Pharmacology 57 598-603. (doi:10.1097/FJC.0b013e3182135f1c)

Magness RR 1998 Maternal cardiovascular and other physiologic responses to the endocrinology of pregnancy. In The Endocrinology of Pregnancy. Ed B Fuller. pp 507-538. Totowa, NJ: Humana Press.

Magness RR, Phernetton TM, Gibson TC \& Chen CB 2005 Uterine blood flow responses to ICI 182780 in ovarioectomized oestradiol-17 $\beta$-treated, intact follicular and pregnant sheep. Journal of Physiology 565 71-83. (doi:10.1113/jphysiol.2005.086439) 
Meyers MJ, Sun J, Carlson KE, Marriner GA, Katzenellenbogen JA \& Katzenellenbogen BS 2001 Estrogen receptor- $\beta$ potency-selective ligands: structure-activity relationship studies of diarylpropionitriles and their acetylene and polar analogues. Journal of Medicinal Chemistry 44 4230-4251. (doi:10.1021/jm010254a)

Montgomory S, Shaw L, Pantelides N, Taggart M \& Austin C 2003 Acute effects of oestrogen receptor subtype-specific agonists on vascular reactivity. British Journal of Pharmacology 139 1249-1253. (doi:10.1038/sj.bjp.0705368)

Mulvany W \& Halpern MJ 1977 Tension responses to small length changes of vascular smooth muscle cells. Journal of Physiology $26521 \mathrm{P}-23 \mathrm{P}$.

Naderali EK, Walker AB, Doyle P \& Williams G 1999 Comparable vasorelaxant effects of $17 \alpha$ - and $17 \beta$ oestradiol on rat mesenteric resistance arteries: an action independent of the oestrogen receptor. Clinical Science $\mathbf{9 7}$ 649-655. (doi:10.1042/CS19990162)

Nakajima T, Kitazawa T, Hamada E, Hazama H, Omata M \& Kurachi Y 1995 $17-\beta$-Estradiol inhibits the voltage-dependent L-type $\mathrm{Ca}^{2+}$ currents in aortic smooth muscle cells. European Journal of Pharmacology 294 625-635. (doi:10.1016/0014-2999(95)00602-8)

Osol G, Cipolla M \& Knutson S 1989 A new method for mechanically denuding the endothelium of small (50-150 microns) arteries with a human hair. Blood Vessels 26 320-324.

Rosenfeld CR, Cox BE, Roy T \& Magness RR 1996 Nitric oxide contributes to estrogen-induced vasodilation of the ovine uterine circulation. Journal of Clinical Investigation 98 2158-2166. (doi:10.1172/ JCI119022)

Rosenfeld CR, White RE, Roy T \& Cox BE 2000 Calcium-activated potassium channels and nitric oxide coregulate estrogen-induced vasodilation. American Journal of Physiology. Heart and Circulatory Physiology 279 H319-H328.

Schwers J, Govaerts-Videtsky M, Wiqveist N \& Diczfalusy E 1965 Metabolism of oestrone sulphate by the previable human foetus. Acta Endocrinologica 50 597-610.

Scott PA, Tremblay A, Brochu M \& St-Louis J 2007 Vasorelaxant action of $17 \beta$-estradiol in rat uterine arteries: role of nitric oxide synthases and estrogen receptors. American Journal of Physiology. Heart and Circulatory Physiology 293 H3713-H3719. (doi:10.1152/ajpheart.00736.2007)
Shan J, Resnick LM, Liu Q-Y, Wu X-C, Barbagallo M \& Pang PKT 1994 Vascular effects of $17 \beta$-estradiol in male Sprague-Dawley rats. American Journal of Physiology. Heart and Circulatory Physiology 266 H967-H973.

Somlyo AP \& Somlyo AV 1994 Signal transduction and regulation in smooth muscle. Nature 372 231-236. (doi:10.1038/372231a0)

Stauffer SR, Coletta CJ, Tedesco R, Nishiguchi G, Carlson K, Sun J, Katzenellenbogen JA \& Katzenellenbogen BS 2000 Pyrazole ligands: structure-affinity/activity relationships and estrogen receptor- $\alpha$-selective agonists. Journal of Medicinal Chemistry 43 4934-4947. (doi:10.1021/ jm000170m)

Van Buren GA, Yang DS \& Clark KE 1992 Estrogen-induced uterine vasodilatation is antagonized by L-nitroarginine methyl ester, an inhibitor of nitric oxide synthesis. American Journal of Obstetrics and Gynecology 167 828-833.

Visser M \& Coelingh Bennink HJT 2009 Clinical applications for estetrol. Journal of Steroid Biochemistry and Molecular Biology 114 85-89. (doi:10.1016/ j.jsbmb.2008.12.013)

Visser M, Foidart J-M \& Coelingh Bennink HJT 2008 In vitro effects of estetrol on receptor binding, drug targets and human liver cell metabolism. Climacteric 11 (Suppl 1) 31-40. (doi:10.1080/13697130802056511)

Wakeling AE, Dukes M \& Bowler J 1991 A potent specific pure antiestrogen with clinical potential. Cancer Research 51 3867-3873.

Wulff H, Miller MJ, Hansel W, Grissmer S, Cahalan MD \& Chandy KG 2000 Design of a potent and selective inhibitor of the intermediate-conductance $\mathrm{Ca}^{2+}$-activated $\mathrm{K}^{+}$channel, IKCa1: a potential immunosuppressant. PNAS 97 8151-8156. (doi:10.1073/pnas.97.14.8151)

Zhang F, Ram JL, Standley PR \& Sowers JR 1994 17 $\beta$-Estradiol attenuates voltage-dependent $\mathrm{Ca}^{2+}$ currents in A7r5 vascular smooth muscle cell line. American Journal of Physiology. Cell Physiology 266 C975-C980.

Received in final form 7 June 2012

Accepted 13 July 2012

Made available online as an Accepted Preprint 13 July 2012 